\title{
Edukasi Penanganan dan Penyimpanan Makanan saat Kondisi Pandemi Covid-19 pada Ibu Rumah Tangga Komunitas "Yuk Main"
}

\author{
Nurul Azizah Choiriyah \\ Program studi Seni Kuliner, Akademi Kuliner dan Patiseri OTTIMMO Internasional \\ Jalan Bukit Telaga Golf TC4/2-3 Citraland, Surabaya, Jawa Timur \\ nurul.azizah.choiriyah@gmail.com
}

\begin{abstract}
Abstrak
Pada masa pandemi covid-19, masyarakat perlu menyetok makanan dan menyimpannya dengan benar agar masyarakat tidak perlu untuk sering ke luar rumah hanya sekedar membeli makanan saja. Beberapa bahan makanan ada yang bersifat perishable (mudah rusak) dan non-perishable (tidak mudah rusak). Komunitas "YUK MAIN" merupakan komunitas yang di dalamnya berisikan ibu rumah tangga yang berasal dari Kudus yang memiliki anak usia 3-6 tahun. Tujuan dari pengabdian masyarakat ini adalah untuk meningkatkan pengetahuan mengenai penanganan dan penyimpanan makanan saat kondisi pandemi covid-19. Pelaksanaan kegiatan ini dilakukan dengan penyuluhan. Kegiatan dilakukan terhadap 36 anggota komunitas "Yuk Main". Ibu rumah tangga tersebut memiliki motivasi yang tinggi dalam mengikuti penyuluhan, antusias pada saat sesi tanya jawab.
\end{abstract}

Kata kunci : ibu rumah tangga, penyuluhan, penyimpanan pangan, penanganan pangan, perishable food

\begin{abstract}
During covid-19 pandemic, people needed to supply some foods and store it properly so that they did not need to go out often. Some foods are perishable. "YUK MAIN" community is a community that the members are housewives from Kudus who have children aged 3-11 years. The aim of this community service was to increase knowledge about food handling and storage during the covid-19 pandemic conditions. The implementation of this activity is done by counseling. Activities were carried out on 36 members of the "Yuk Main" community. This community have high motivation in this counseling, enthusiastic in the question and answer session.
\end{abstract}

Keywords: housewife, counseling, food storage, food handling, perishable food

\section{PENDAHULUAN}

Pada Desember 2019, China mengumumkan seri dari pneumonia yang mana penyebabnya belum diketahui dan kemudian berkembang sebagai pandemi Covid-19. Asal mula virus yang menyebabkan covid-19, SARS-COV-2 masih belum diketahui secara pasti dan hal ini terus dilakukan investagasi. Covid-19 merupakan penyakit zoonotic, penyebarannya dari hewan ke manusia. Dalam kasus covid-19, hewan liar merupakan 
inang asli kemudian menyebar ke hewan lain yang diperdagangkan di pasar basah, yang menularkan penyakit kepada manusia (Bakalis et al., 2020).

Menurut Bakalis et al., 2020 sampai pada Mei 2020, sejumlah 3,5 juta orang lebih penduduk di dunia telah terinfeksi covid-19 dan estimasi yang diajukan mencapai 100 kali lebih banyak. Sepertiga populasi global berada pada wilayah yang dilockdown. Di Indonesia, beberapa kota menerapkan PSBB (Pembatasan Sosial Berskala Besar).

Pada masa pandemi covid-19, masyarakat perlu menyetok makanan dan menyimpannya dengan benar agar masyarakat tidak perlu untuk sering ke luar rumah hanya sekedar membeli makanan saja. Beberapa bahan makanan ada yang bersifat perishable (mudah rusak) dan non-perishable (tidak mudah rusak). Bahan hasil pertanian seperti buah-buahan dan sayur-sayuran merupakan bahan yang mudah rusak (Onggo et al., 2019). Selain itu, bahan yang kaya akan nutrisi seperti telur, susu, daging dan unggas juga merupakan bahan perishable.

Kerusakan makanan sangat dipengaruhi oleh aktivitas antimikroba. Pengendalian antimikroba dapat dilakukan dengan kontrol suhu (Aung \& Chang, 2014). Ibu rumah tangga memegang peran penting dalam penyediaan, penanganan dan penyimpanan bahan makanan. Sayangnya, banyak ibu rumah tangga yang belum mengerti bagaimana cara penanganan dan penyimpanan bahan makanan yang baik agar tahan lama. Dengan adanya pengetahuan mengenai penanganan dan penyimpanan bahan makanan yang baik diharapkan dapat membantu ibu rumah tangga dalam menyediakan stok pangan yang cukup lama selama pandemi covid-19.

Komunitas "YUK MAIN" merupakan komunitas yang di dalamnya berisikan ibu rumah tangga yang berasal dari Kudus yang memiliki anak usia 3-11 tahun, dibentuk pada tahun 2016. Kegiatan yang terdapat pada komunitas ini diantaranya belajar dan bermain pada anak-anak yang melibatkan aktivitas fisik sehingga dapat mengurangi paparan gadget pada anak-anak. Kegiatan bermain dan belajar bersama diadakan setiap bulan. Selain itu pada komunitas YUK MAIN juga terdapat sesi "Parents Corner". Sesi parents corner dilakukan sebulan sekali. Pada sesi ini, ibu rumah tangga saling bertukar pendapat dan juga mendapatkan edukasi ataupun ilmu dari seorang narasumber tertentu sesuai tema yang diadakan.

Dengan meminimalkan seseorang untuk pergi keluar rumah maka dapat membantu dalam memutus penyebaran covid-19. Tujuan dari pengabdian masyarakat ini 
adalah untuk meningkatkan pengetahuan mengenai penyediaan jumlah beras, air mineral, minyak goreng, telur, daging sapi, bumbu pelengkap, frozen food dan susu yang harus dibeli untuk persediaan per 2 minggu; penyimpanan bahan-bahan tersebut agar tidak rusak selama penyimpanan; penanganan dan penyimpanan produk buah-buahan dan sayur-sayuran; bahan pengganti beras yang dapat digunakan sebagai alternatif makanan pokok misalnya ubi jalar, sorgum, tiwul, beras analog dari jagung dan singkong pada ibu rumah tangga komunitas "YUK MAIN". Pelaksanaan kegiatan ini dilakukan dengan penyuluhan.

\section{METODE}

Kegiatan penyuluhan ini dilakukan dengan cara KULWAP (Kuliah Whatsapp). Tahap pelaksanaan kegiatan penyuluhan dimulai dengan prasurvey komunitas ibu rumah tangga melalui media internet. Penetapan sasaran penyuluhan yaitu pada komunitas Ibu rumah tangga "YUK MAIN". Alasan pemilihan komunitas ini karena komunitas ini aktif melakukan kegiatan setiap bulan. Kegiatan pertemuan anggota setiap bulan pada masa pandemi covid-19 tetap digantikan melalui daring. Komunitas tersebut juga aktif dalam share kegiatan di media sosial seperti Instagram dan blog. Pada waktu melakukan koordinasi dengan pengurus komunitas ini, pengurus tersebut juga sangat responsif. Tahapan pelaksanaan setelah penetapan sasaran adalah menyelesaikan persetujuan kerja sama dengan komunitas "YUK MAIN", penentuan waktu penyuluhan, pembuatan poster kegiatan penyuluhan, pembuatan materi penyuluhan dan penyebaran informasi tentang kegiatan penyuluhan yang akan diadakan kepada anggota komunitas "YUK MAIN". Kegiatan penyuluhan dilakukan pada Sabtu, 18 April 2020 pukul 18.00 hingga 21.30 WIB. Pada waktu pelaksanaan, pengurus komunitas "YUK MAIN" berkoordinasi dengan pemateri dan memasukkan pemateri dalam grup Whatsapp.

Judul materi pada kulwap yaitu penanganan dan penyimpanan bahan makanan pada kondisi pandemi covid-19. Isi Materi diantaranya saran penyediaan jumlah beras, air mineral, minyak goreng, telur, daging sapi, bumbu pelengkap, frozen food dan susu yang harus dibeli untuk persediaan per 2 minggu; penyimpanan bahan-bahan tersebut agar tidak rusak selama penyimpanan; untuk buah-buahan dan sayur-sayuran ada saran khusus karena sifatnya yang perishable; bahan pengganti beras yang digunakan sebagai alternatif makanan pokok misalnya ubi jalar, sorgum, tiwul, beras analog dari jagung dan singkong. 
Rundown acara kulwap ini yaitu pembukaan oleh moderator dan penulisan daftar hadir peserta, sambutan dari ketua komunitas, penyampaian materi dan pemaparannya dalam bentuk soft file pdf yang disebarkan pada grup Whatsapp komunitas Yuk Main, kemudian dilanjutkan dengan sesi tanya jawab. Sesi Tanya jawab dibagi dalam 3 termin. Pertanyaan berhubungan dengan materi yang telah disampaikan. Peserta antusias dalam bertanya terbukti dengan banyaknya peserta yang ingin bertanya dan beranekaragamnya pertanyaan yang diajukan. Peserta juga merasa terbantu atas materi Kulwap. Diakhir sesi kulwap, moderator memberikan kesimpulan atas kulwap yang telah berjalan serta pemateri memberikan ajakan agar ibu rumah tangga yang mengikuti kulwap juga menyebarluaskan informasi yang diperoleh. Aktivitas penyuluhan ini diikuti oleh 41 orang dengan sebaran sebagai berikut pemateri (dosen) 1 orang, pengurus komunitas "YUK MAIN" 4 orang, anggota komunitas "YUK MAIN" 36 orang.

\section{HASIL DAN PEMBAHASAN}

Kegiatan penyuluhan ini dibutuhkan waktu dua minggu untuk tahap prasurvey komunitas, menyelesaikan persetujuan kerja sama penyuluhan, penentuan waktu penyuluhan dan kegiatan, penyebaran informasi kegiatan kepada anggota komunitas hingga penyuluhan itu sendiri. Hasil pengabdian masyarakat ini meninjau motivasi ibu rumah tangga dalam mengikuti kegiatan penyuluhan dan antusiasme ibu rumah tangga selama penyuluhan berlangsung. Ibu rumah tangga komunitas "YUK MAIN" memiliki motivasi tinggi dalam mengikuti kegiatan penyuluhan. Hal ini dibuktikan dengan banyaknya peserta yang mengkonfimasi kehadiran melalui whatsapp saat panitia mengabsen anggota pada waktu kegiatan.

Pemaparan materi dalam kegiatan penyuluhan adalah sebagai berikut kebutuhan beras untuk waktu dua minggu dapat menyediakan beras $20 \mathrm{~kg}$ untuk satu keluarga yang berisi 4 orang. Agar beras tahan lama, beras yang dibeli sebaiknya dengan ukuran $5 \mathrm{~kg}$ per kemasan. Di waktu pandemi covid-19, program pemerintah mengenai pangan lokal juga perlu didukung misalnya mengganti beras dengan beras analog yang sekarang ini sudah banyak dijual di marketplace maupun pasaran. Persediaan minyak goreng untuk waktu 2 minggu bisa disiapkan minyak sebanyak 2 liter.

Persediaan telur untuk kebutuhan rumah tangga dengan 4 orang anak, dapat disiapkan telur sebanyak 30 butir. Iqbal et al., (2018) menyatakan telur merupakan bahan 
yang mudah rusak, sehingga apabila menyediakan dalam jumlah yang lebih banyak dikhawatirkan rusak. Telur dapat disimpan dalam lemari es suhu $4^{\circ} \mathrm{C}$. Namun mengingat kapasitas lemari es terbatas, maka tidak mungkin untuk membeli terlalu banyak. Untuk mengurangi overload lemari es, sejumlah 10 telur dapat disimpan di suhu ruang dan penggunaanya diutamakan terlebih dahulu untuk meminimalkan kerusakan.

Daging sapi dan unggas juga merupakan bahan yang mudah rusak. Penyimpanan dalam freezer suhu di bawah $-18^{\circ} \mathrm{C}$ merupakan cara yang tepat untuk meminimalkan kerusakan mikrobiologis (Muhammad et al., 2018). Daging sapi dapat dibeli per satu kilogram. Unggas dapat dibeli per dua kg.

Bumbu juga perlu disiapkan dengan memperkirakan kelengkapan bumbu. Beberapa bumbu tertentu bisa ditanam sendiri di rumah misalnya serai, kunyit, daun salam dan lain sebagainya. Bumbu berbentuk bubuk juga dapat disimpan dengan umur simpan yang lebih lama dibandingkan bumbu segar. Bawang merah dan bawang putih dapat dibeli $1 \mathrm{~kg}$ untuk persediaan 2 minggu. Penyimpanan bawang merah dan bawang putih adalah dihamparkan pada ruangan terbuka suhu ruang.

Penyediaan frozen food dapat dilakukan dengan mengolah sendiri agar lebih sehat. Telah diketahui bahwa anak anak sangat menyukai produk frozen food seperti nugget. Nugget dapat dibuat dari bahan protein tinggi dengan harga murah seperti tempe (Astawan et al., 2014) dan dicampur dengan sayuran . Sehingga nugget tersebut mengandung serat tinggi. Siapkan nugget 750 gram untuk kebutuhan waktu 2 minggu. Nugget tersebut harus diismpan dalam freezer suhu $-18^{\circ} \mathrm{C}$.

Manusia membutuhkan air sebanyak dua liter perhari. Untuk kebutuhan 2 minggu maka air minum yang dibutuhkan adalah 2 liter dikalikan jumlah anggota keluarga dikalikan 14 hari. Membeli air mineral melalui fasilitas telephone atau handphone lebih dianjurkan.

Susu merupakan pelengkap gizi. Kebutuhan susu dapat dilakukan dengan membeli produk susu UHT dan susu bubuk. Susu UHT yang belum dibuka dan susu bubuk dapat disimpan pada suhu ruang. Sedangkan susu pasteurisasi harus disimpan dalam lemari es $4^{\circ} \mathrm{C}$. Kebutuhan susu dapat membeli per 3 liter susu UHT atau susu bubuk kemasan 400 gram untuk kebutuhan 2 minggu per orang.

Bahan sayuran dan buah-buahan segar perlu mendapatkan perhatian khusus. Karena untuk menjaga kesegaran dari bahan tersebut maka penyediaan bahan tersebut 
dilakukan untuk 4 hari sekali. Buah dan sayur perlu disimpan dalam lemari es suhu $4^{\circ} \mathrm{C}$ untuk menjaga kesegaran. Untuk persediaan yang cukup lama yaitu 2 minggu, sayur beku dan buah-buahan kering dapat dijadikan pilihan. Beberapa buah dan sayuran lebih baik untuk disimpan suhu ruang untuk menghindari chilling injury adalah alpukat (Endo et al., 2019), pisang (Khademi et al., 2019) dan tomat (Park et al., 2018). Strategi untuk menyimpan buah adalah membeli buah klimakterik dalam kondisi masih mentah seperti pisang mentah, dan alpukat mentah sehingga dapat menyetok persediaan buah untuk waktu yang lebih lama yaitu 1 minggu.

Untuk penyimpanan sayuran seperti kankung dan bayam, dapat dihilangkan dahulu bagian akar dan batang kemudian dimasukkan dalam plastik klip dan barulah dimasukkan ke dalam lemari es. Apabila perlu untuk berbelanja ke tukang sayur keliling untuk menyetok kembali buah-buahan dan sayuran maka perlu untuk memperhatikan protokol kesehatan kemudian sebaiknya mencatat terlebih dahulu bahan apa saja yang perlu dibeli sehingga aktivitas berbelanja dapat dikerjakan dengan cepat.

Macam dan jumlah bahan makanan yang dibutuhkan setiap keluarga untuk bahan makanan sangat bervariasi. Namun materi penyuluhan tersebut dapat dijadikan referensi untuk meminimalkan aktivitas di luar rumah saat pandemi covid-19. Menurut (Hassan \& Dimassi, 2014) penataan lokasi saat menyimpan bahan makanan juga perlu diperhatikan. Dalam lemari es, makanan yang matang harus disimpan pada rak lemari es paling atas. Kemudian bahan daging harus diletakkan pada rak bagian bawah. Telur ditempatkan pada rak khusus telur yang biasanya terdapat pada bagian pintu.

Ibu rumah tangga komunitas "YUK MAIN" memiliki antusiasme yang tinggi selama kegiatan penyuluhan berlangsung. Tanya jawab seputar materi berlangsung dengan seru karena banyaknya dan beranekaragamnya pertanyaan yang diajukan. Pengetahuan mengenai penyediaan jumlah beras, air mineral, minyak goreng, telur, daging sapi, bumbu pelengkap, frozen food dan susu yang harus dibeli untuk persediaan per 2 minggu; penyimpanan bahan-bahan tersebut agar tidak rusak selama penyimpanan; penanganan dan penyimpanan produk buah-buahan dan sayur-sayuran; bahan pengganti beras yang dapat digunakan sebagai alternatif makanan pokok misalnya ubi jalar, sorgum, tiwul, beras analog dari jagung dan singkong pada ibu rumah tangga komunitas "YUK MAIN" menjadi meningkat. Hal ini dibuktikan dengan pertanyaan yang diajukan berbobot sesuai dengan 
materi yang disampaikan. Kendala yang dirasakan pada penyuluhan ini yaitu adanya peserta penyuluhan yang tidak mengikuti arahan dari moderator waktu bertanya.

\section{SIMPULAN}

Keadaan pandemi covid-19 telah menjadikan masyarakat menjadi adaptif dalam menerima ilmu pengetahuan melalui daring. Kegiatan penyuluhan melalui kulwap ini berhasil meningkatkan pengetahuan ibu rumah tangga komunitas "YUK MAIN" mengenai penyediaan jumlah beras, air mineral, minyak goreng, telur, daging sapi, bumbu pelengkap, frozen food dan susu yang harus dibeli untuk persediaan per 2 minggu; penyimpanan bahan-bahan tersebut agar tidak rusak selama penyimpanan; penanganan dan penyimpanan produk buah-buahan dan sayur-sayuran; bahan pengganti beras yang dapat digunakan sebagai alternatif makanan pokok misalnya ubi jalar, sorgum, tiwul, beras analog dari jagung dan singkong. Ibu rumah tangga tersebut memiliki motivasi yang tinggi dalam mengikuti penyuluhan, antusias pada saat sesi tanya jawab dan lebih dari $95 \%$ peserta mengikuti arahan moderator dengan baik.

\section{DAFTAR PUSTAKA}

Astawan, M., Adiningsih, N. R., \& Palupi, N. S. (2014). Evaluasi Kualitas Nuget Tempe dari Berbagai Varietas Kedelai. Institut Pertanian Bogor, 23(3) 244-255.

Aung, M. M., \& Chang, Y. S. (2014). Temperature management for the quality assurance of a perishable food supply chain. Food Control, 40(1), 198-207. https://doi.org/10.1016/j.foodcont.2013.11.016

Bakalis, S., Valdramidis, V., Argyropoulos, D., Ahrne, L., Cullen, P. J., Cummins, E., Datta, A. K., Emmanouilidis, C., Fryer, P., Gouseti, O., Hospido, A., Knoerzer, K., Lebail, A., Marangoni, A., Rao, P., Schlüter, O., Taoukis, P., \& Impe, J. Van. (2020). How COVID19 changed our food systems and food security paradigms. Current Research in Food Science. https://doi.org/10.1016/j.crfs.2020.05.003

Hassan, H. F., \& Dimassi, H. (2014). Food safety and handling knowledge and practices of Lebanese university students. Food Control, 40, 127-133. https://doi.org/10.1016/j.foodcont.2013.11.040 
Jurnal Pelayanan dan Pengabdian Masyarakat (PAMAS)

Muhammad, I., Choiriyah, N. A., \& Yunita, S. I. (2018). Evaluating nutrition students' knowledge of food safety in indonesia: Multi-strata comparison review. Pakistan Journal of Nutrition, 17(12), 666-670. https://doi.org/10.3923/pjn.2018.666.670

Onggo, B. S., Panadero, J., Corlu, C. G., \& Juan, A. A. (2019). Agri-food supply chains with stochastic demands: A multi-period inventory routing problem with perishable products. Simulation Modelling Practice and Theory, 97(August), 101970. https://doi.org/10.1016/j.simpat.2019.101970 